\title{
Regulation of Sodium Absorption by Canine Tracheal Epithelium
}

\author{
Joseph J. Cullen and Michael J. Welsh \\ Laboratory of Epithelial Transport and Pulmonary Division, Department of Internal Medicine, \\ University of Iowa College of Medicine, Iowa City, Iowa 52242
}

\begin{abstract}
To regulate the quantity of respiratory tract fluid, the airway epithelium either secretes chloride, $\mathrm{Cl}^{-}$, or reabsorbs sodium, $\mathrm{Na}^{+}$. Many secretagogues inhibit $\mathrm{Na}^{+}$absorption, but the decrease may result from a fall in the electrochemical gradient for $\mathrm{Na}^{+}$absorption. We examined regulation of $\mathrm{Na}^{+}$absorption independent of $\mathrm{Cl}^{-}$secretion, by bathing canine tracheal epithelium in $\mathrm{Cl}^{-}$-free, gluconate Ringers solution. Prostaglandin $\mathrm{E}_{2}, 2$ chloroadenosine, and isoproterenol increased short-circuit current (Isc) and the rate of $\mathrm{Na}^{+}$absorption. In contrast, indomethacin, which inhibits endogenous prostaglandin production, decreased Isc. These agents regulate cellular levels of cAMP; direct addition of 8-Br-cAMP also acutely increased Isc. We examined chronic regulation of $\mathrm{Na}^{+}$absorption in cell monolayers grown on permeable supports in serum-free media. Exposure to aldosterone for two days increased baseline Isc by $50 \%$ and the amilorideinhibitable current by $55 \%$. These data indicate that $\mathrm{Na}^{+}$absorption is both acutely and chronically regulated in the airway epithelium.
\end{abstract}

\section{Introduction}

Tracheal epithelium has the capacity for both active $\mathrm{Cl}^{-}$secretion and active $\mathrm{Na}^{+}$absorption (1). The relative magnitude of these two transport processes determines whether the epithelium will secrete or absorb fluid. Although many neurohumoral agents are known to regulate $\mathrm{Cl}^{-}$secretion, much less is known about the direct regulation of $\mathrm{Na}^{+}$absorption. Previous reports show that many agents that stimulate $\mathrm{Cl}^{-}$secretion produce a simultaneous fall in the rate of $\mathrm{Na}^{+}$absorption (2-4). However, such a decrease might be secondary to a decrease in the electrochemical gradient favoring $\mathrm{Na}^{+}$entry into the cell across the apical membrane: secretagogues depolarize the electrical potential difference across the apical membrane (5) and increase intracellular $\mathrm{Na}^{+}$activity (6).

The purpose of this study was to directly examine the regulation of $\mathrm{Na}^{+}$absorption. To examine acute regulation we bathed tissues in $\mathrm{Cl}^{-}$-free media so that $\mathrm{Na}^{+}$absorption would not be secondarily altered by changes in $\mathrm{Cl}^{-}$secretion or $\mathrm{Cl}^{-}$ conductance. We examined several neurohumoral agents known to have receptors on the epithelial cells and known to regulate

Address reprint requests to Dr. Welsh.

Received for publication 27 May 1986.

J. Clin. Invest.

(C) The American Society for Clinical Investigation, Inc.

0021-9738/87/01/0073/07 \$1.00

Volume 79, January 1987, 73-79
$\mathrm{Cl}^{-}$secretion. To examine chronic regulation we grew cultured cells in aldosterone-containing media.

\section{Methods}

The posterior membranous portion of dog tracheal epithelium was prepared as previously described (7). The bathing solution was a modified $\mathrm{Cl}^{-}$-free Ringer's solution containing (in $\mathrm{mM}$ ): $139.3 \mathrm{Na}$-gluconate, 0.6 $\mathrm{KH}_{2} \mathrm{PO}_{4}, 2.4 \mathrm{~K}_{2} \mathrm{HPO}_{4}, 1.2 \mathrm{MgSO}_{4}, 10$ glucose, and 10 Hepes (buffered to $\mathrm{pH}$ 7.4). In our first experiments we used $1.2 \mathrm{mM} \mathrm{CaSO}_{4}$, but because gluconate buffers $\mathrm{Ca}^{2+}(8)$, in most experiments we used $10 \mathrm{mM} \mathrm{CaSO}_{4}$. Tissues bathed in media that contained $10 \mathrm{mM} \mathrm{CaSO}_{4}$ had a more stable resistance, but the response to addition of hormones was the same. This later finding is consistent with previous observations that the active transport properties of trachea show little dependence on extracellular $\mathrm{Ca}^{2+}$ (9). After removal from the animal, the tissue was placed in $\mathrm{Cl}^{-}$free Ringer's solution. When the tissues were mounted in chambers they were bathed with the $\mathrm{Cl}^{-}$-free solution, which was replaced twice at halfhour intervals to remove residual $\mathrm{Cl}^{-}$. Salt bridges were $140 \mathrm{mM} \mathrm{Na}-$ gluconate $/ 4 \%$ agar. Solutions were bubbled with $100 \% \mathrm{O}_{2}$ and maintained at $37^{\circ} \mathrm{C}$.

Tracheal epithelial cells were isolated and grown in tissue culture as previously described $(10,11)$, except that the filters were attached to the bottom of a Lucite tube (exposed area $0.64 \mathrm{~cm}^{2}$ ). The media was a 1:1 mixture of Dulbecco's modified Eagle's medium and Ham's F-12 containing $10 \%$ fetal calf serum for the first 5-6 d in culture. Then the fetal calf serum was deleted from the media and aldosterone was added to some of the monolayers. The media of both control and aldosteronetreated monolayers was changed after $1 \mathrm{~d}$ and the monolayers were studied $1 \mathrm{~d}$ later. During measurement of the electrical properties, monolayers were bathed symmetrically with a phosphate-buffered $\mathrm{NaCl}$-Ringer's solution $\left(37^{\circ} \mathrm{C}\right.$, equilibrated with room air, $\left.\mathrm{pH}=7.4\right)$.

For measurement of transepithelial electrical properties and radioisotope fluxes, tissues were mounted in Ussing chambers $\left(1.5\right.$ or $0.2 \mathrm{~cm}^{2}$ surface area) and monolayers were mounted in a specially adapted Ussing chamber. The transepithelial electrical potential difference (referenced to the mucosal solution) was automatically clamped to zero (the shortcircuit condition) by automatic voltage-current clamps. Transepithelial slope conductance $\left(G_{t}\right)$ was calculated from the change in current required to clamp transepithelial voltage to $\pm 10 \mathrm{mV}$ (duration $1 \mathrm{~s}$; period $50 \mathrm{~s}$ ). For the measurement of unidirectional transepithelial fluxes of $\mathrm{Na}^{+}, 5$ $\mu \mathrm{Ci}$ of ${ }^{22} \mathrm{Na}$ was added to the appropriate side of the tissue (the volume of fluid on each side of the tissue was $8 \mathrm{ml}$ ). $1 \mathrm{~h}$ was allowed for fluxes of $\mathrm{Na}^{22}$ to reach steady state and then three to four samples of both bathing solutions were taken at 10 - to 20 -min intervals during each control and experimental period.

Chloride concentrations were measured with a chloridometer (Laboratory Glass and Instruments Corp., New York). Chemicals used were isoproterenol (Elkins-Sinn, Inc., Cherry Hill, NJ); $\mathrm{PGE}_{2}, 8-\mathrm{Br}-\mathrm{cAMP}$, 2-chloroadenosine, indomethacin (Sigma Chemical Co., St. Louis, MO); propranolol (Ayerst Laboratories Inc., New York), phenylephrine (Winthrop Laboratories, New York), and A-23187 (Calbiochem-Behring Corp., La Jolla, CA).

Results are presented as means \pm SEM. Statistical significance was evaluated using a paired $t$ test; a $P$ value $<0.05$ was considered statistically significant. 


\section{Results}

Effect of hormones and mediators on short circuit current (Isc). ${ }^{1}$ Prostaglandin $\mathrm{E}_{2}\left(\mathrm{PGE}_{2}\right)$ stimulates the rate of $\mathrm{Cl}^{-}$secretion and prostaglandin production by the epithelium regulates the baseline rate of $\mathrm{Cl}^{-}$secretion $(2,5,12)$. To determine if prostaglandins had an effect on $\mathrm{Na}^{+}$absorption, we examined the effect of $\mathrm{PGE}_{2}$ on the electrical properties of tissues bathed in $\mathrm{Cl}^{-}$-free media. Fig. 1 shows that $\mathrm{PGE}_{2}$ added to the submucosal solution increased Isc, suggesting an increase in $\mathrm{Na}^{+}$absorption. In contrast to its effect on $\mathrm{Cl}^{-}$secretion which is quite rapid, $\mathrm{PGE}_{2}$ produced a slow increase in Isc, with Isc reaching a maximum at $\sim 1 \mathrm{~h}$.

We also examined the effect of two other agents that regulate ion transport in tracheal epithelium $(13,14)$. Table I shows that the $\beta$-adrenergic agonist, isoproterenol $\left(5 \times 10^{-6} \mathrm{M}\right.$, submucosal solution) and the adenosine analogue, 2 -chloroadenosine $\left(10^{-5}\right.$ $\mathrm{M}$, mucosal solution) also increased Isc. Although the changes in Isc were small, they were consistent.

To determine if endogenous prostaglandin production by the epithelium may play some role in regulating $\mathrm{Na}^{+}$absorption, we examined the effect of adding the prostaglandin synthesis inhibitor indomethacin $\left(10^{-6} \mathrm{M}\right)$ to the mucosal solution. Fig. 2 shows that indomethacin decreased Isc, suggesting a decrease in the rate of $\mathrm{Na}^{+}$absorption. Fig. 3 shows that the magnitude of the decrease in Isc produced by indomethacin was dependent on the initial value of Isc, providing further support for the notion that endogenous prostaglandin production by the epithelium regulates the baseline rate of $\mathrm{Na}^{+}$absorption. To be sure that indomethacin did not produce a nonspecific decrease in Isc or a toxic effect, we examined the Isc response to isoproterenol in indomethacin-treated tissues. Table II shows that indomethacin decreased Isc compared to control tissues but did not prevent the response to subsequent addition of isoproterenol. Following addition of isoproterenol, Isc was the same for tissues that did and did not receive indomethacin.

Prostaglandin $\mathrm{E}_{2}$, isoproterenol, and 2-chloroadenosine increase and indomethacin decreases cellular levels of cAMP in tracheal epithelium $(2,12,14)$. It thus seemed likely that cAMP might also be responsible for the increase in Isc observed in $\mathrm{Cl}^{-}$free media. To test this possibility, we examined the effect of exogenous addition of cAMP. Table III shows that 8-Br-cAMP $\left(5 \times 10^{-5} \mathrm{M}\right)$ added to the mucosal and submucosal solutions also increased Isc. These observations suggest that cAMP may increase $\mathrm{Na}^{+}$absorption.

We also examined the effect of the $\alpha$-adrenergic agonist phenylephrine. Tissues were pretreated with propranolol $\left(10^{-5}\right.$ $M$ mucosal and submucosal solutions) to block any $\beta$-adrenergic effects. Subsequent addition of phenylephrine $\left(10^{-6} \mathrm{M}\right.$, submucosal solution) did not alter the Isc: Isc was $34.7 \pm 6.0$ before and $34.3 \pm 8.0$ after the addition of phenylephrine $(n=7)$.

An increase in cell calcium concentration is thought to inhibit $\mathrm{Na}^{+}$absorption in a variety of epithelia $(15,16)$, primarily by inhibiting $\mathrm{Na}^{+}$entry at the apical membrane (17). To determine if an increase in cell calcium might inhibit $\mathrm{Na}^{+}$absorption in airway epithelium, we first stimulated Isc with 8 -Br-cAMP and then added A-23187. Table IV shows that under these conditions the calcium ionophore decreased Isc, suggesting that an increase in cell calcium concentration inhibits $\mathrm{Na}^{+}$absorption.

1. Abbreviations used in this paper: CF, cystic fibrosis; Isc, short circuit current; $\mathrm{PGE}_{2}$, prostaglandin $\mathrm{E}_{2}$.

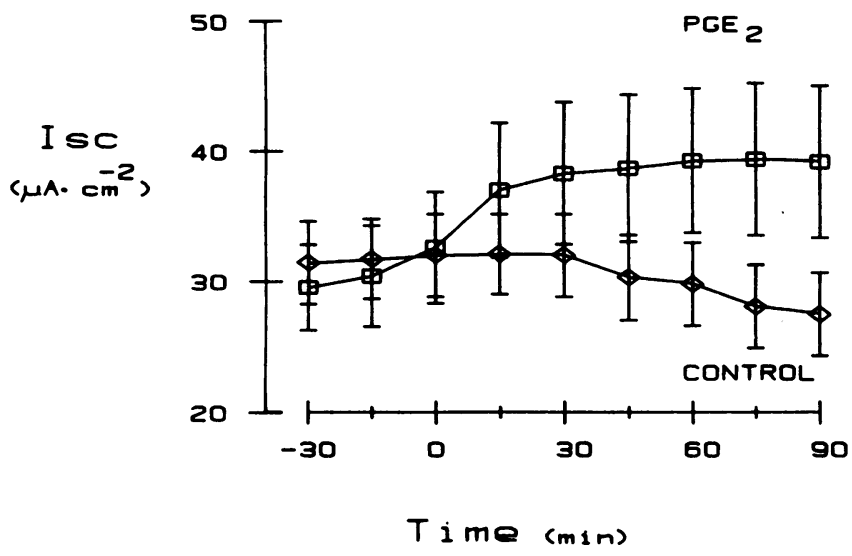

Figure 1. Effect of $\mathrm{PGE}_{2}$ on Isc. $\mathrm{PGE}_{2}\left(10^{-6} \mathrm{M}\right)$ was added to the submucosal solution at time zero. "Control" tissues received no intervention. Values are means \pm SEM for seven tissues.

Changes in Isc result from changes in $\mathrm{Na}^{+}$absorption. The data presented above suggest that changes in Isc resulted from changes in the rate of $\mathrm{Na}^{+}$absorption. The direction of the change in Isc is, in most cases, however, similar to that which would be expected for stimulation of $\mathrm{Cl}^{-}$secretion. To confirm that the changes in Isc resulted from changes in $\mathrm{Na}^{+}$absorption and not $\mathrm{Cl}^{-}$secretion, we did four studies.

First, we measured the $\mathrm{Cl}^{-}$concentration of the bathing solutions taken from the chamber at the end of an experiment: in 10 samples, the highest $\mathrm{Cl}^{-}$concentration was $0.1 \mathrm{mM}$. Moreover, in tissues that were stimulated with isoproterenol or $\mathrm{PGE}_{2}$, addition of $0.5 \mathrm{mM} \mathrm{Cl}^{-}$to the mucosal and submucosal solutions did not alter Isc $(n=4)$. These findings are consistent with the high concentrations of $\mathrm{Cl}^{-}$required to produce a half-maximal rate of $\mathrm{Cl}^{-}$secretion (unpublished observations).

Second, we examined the effect of the loop diuretic bumetanide. Loop diuretics inhibit $\mathrm{Cl}^{-}$secretion in tracheal epithelium by blocking $\mathrm{Cl}^{-}$uptake into the cell at the basolateral membrane $(7,18)$. In three tissues that had been stimulated with 8-Br-cAMP ( $5 \times 10^{-5} \mathrm{M}$, mucosal and submucosal solution), addition of bumetanide $\left(10^{-4} \mathrm{M}\right)$ to the submucosal solution did not alter Isc. Isc was $6.7 \pm 2.7$ before and $6.8 \pm 3.0$ after bumetanide, indicating that there was no appreciable $\mathrm{Cl}^{-}$secretion.

Third, we examined the effect of amiloride, which inhibits electrogenic $\mathrm{Na}^{+}$absorption in tracheal epithelium (4). Amiloride reversed the increase in Isc produced by isoproterenol. Fig. 4 shows that amiloride $\left(10^{-4} \mathrm{M}\right.$, added to the mucosal solution) decreased both Isc and $G_{t}$, consistent with the conclusion that the increase in Isc resulted from electrogenic $\mathrm{Na}$ absorption. We also found that amiloride $\left(10^{-4} \mathrm{M}\right.$, mucosal solution) prevented the increase in Isc produced by 8-Br-cAMP $(n=4)$.

For the studies shown in Fig. 4 we used an amiloride concentration $\left(10^{-4} \mathrm{M}\right)$, which provides maximal inhibition of $\mathrm{Na}^{+}$ absorption. Fig. 5, however, shows that amiloride decreased the Isc at concentrations similar to those required to inhibit electrogenic $\mathrm{Na}^{+}$absorption in other systems (19). Half-maximal inhibition of the Isc was observed at an amiloride concentration of $1.1 \times 10^{-7} \mathrm{M}$.

Fourth, the most direct evidence that $\mathrm{Na}^{+}$absorption increased came from an examination of the effect of isoproterenol on ${ }^{22} \mathrm{Na}$ fluxes. Table $\mathrm{V}$ shows that isoproterenol significantly 
Table I. Effect of Prostaglandin E, Isoproterenol, and 2-Chloroadenosine on Transepithelial Electrical Properties

\begin{tabular}{|c|c|c|c|c|c|c|}
\hline & \multicolumn{2}{|l|}{ Baseline } & \multicolumn{2}{|l|}{ Test } & \multicolumn{2}{|l|}{$\Delta$} \\
\hline & Isc & $G_{\mathrm{t}}$ & Isc & $G_{\mathrm{t}}$ & Isc & $G_{\mathrm{t}}$ \\
\hline Control & $37.3 \pm 6.9$ & $4.11 \pm 0.52$ & $29.0 \pm 7.0$ & $4.16 \pm 0.57$ & $-8.3 \pm 2.2^{*}$ & $0.05 \pm 0.18$ \\
\hline $\mathrm{PGE}_{2}\left(10^{-6} \mathrm{M}\right)$ & $34.1 \pm 10.2$ & $3.23 \pm 0.49$ & $38.8 \pm 14.8$ & $3.15 \pm 0.42$ & $+4.8 \pm 4.8^{\ddagger}$ & $-0.08 \pm 0.23$ \\
\hline Control & $19.0 \pm 6.9$ & $2.69 \pm 0.47$ & $19.2 \pm 7.2$ & $2.65 \pm 0.47$ & $+0.2 \pm 0.5$ & $-0.04 \pm 0.01$ \\
\hline Isoproterenol $\left(5 \times 10^{-6} \mathrm{M}\right)$ & $19.8 \pm 4.8$ & $3.77 \pm 1.16$ & $23.8 \pm 4.9$ & $3.76 \pm 1.19$ & $+4.0 \pm 1.2^{\ddagger *}$ & $-0.01 \pm 0.05$ \\
\hline Control & $15.9 \pm 6.3$ & $2.92 \pm 0.15$ & $15.3 \pm 6.2$ & $2.86 \pm 0.92$ & $-0.6 \pm 1.6$ & $-0.04 \pm 0.13$ \\
\hline 2-chloroadenosine $\left(10^{-5} \mathrm{M}\right)$ & $16.8 \pm 7.3$ & $3.26 \pm 0.92$ & $21.1 \pm 8.5$ & $3.24 \pm 0.86$ & $+4.3 \pm 2.1^{\ddagger}$ & $-0.02 \pm 0.16$ \\
\hline
\end{tabular}

Isc, short-circuit current and $G_{\mathrm{t}}$ to transepithelial conductance. Tissue pairs from the same animal were studied in two consecutive periods: a baseline period and a test period. Control tissues received no intervention between the first and second period while experimental tissues received the agents indicated. Values represent means \pm SEM for eight pairs of tissues for $\mathrm{PGE}_{2}$, six pairs for isoproterenol and five pairs for 2-chloroadenosine. ${ }^{*}$ Indicates a statistical difference between baseline and test periods, $P<0.05$. ${ }^{\ddagger}$ Indicates a statistical difference between control and experimental tissues, $P<0.05$.

increased both net $\mathrm{Na}^{+}$absorption and the $\mathrm{Na}^{+}$flux from the mucosal to submucosal solution.

Effect of aldosterone on $\mathrm{Na}^{+}$absorption. The data presented above indicates that $\mathrm{Na}^{+}$absorption can be acutely regulated.

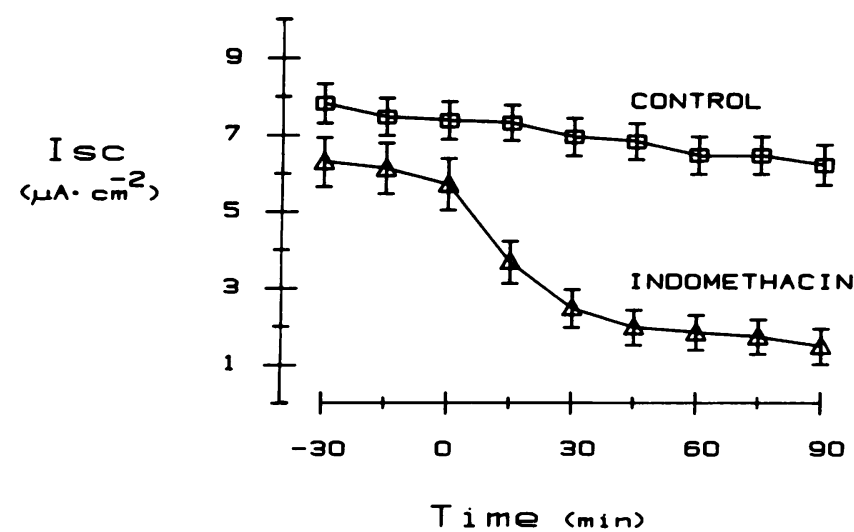

Figure 2. Effect of indomethacin on Isc. Indomethacin $\left(10^{-6} \mathrm{M}\right)$ was added to the mucosal solution at the time zero. "Control" tissues received no intervention. Values are means \pm SEM for 10 tissues.

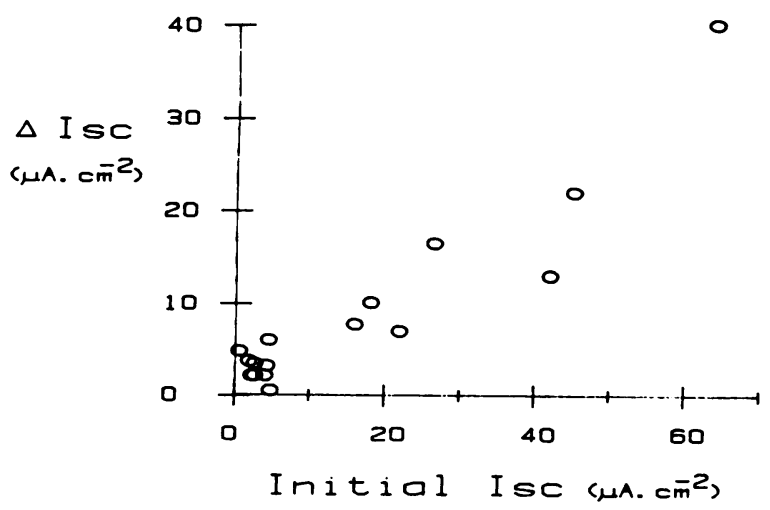

Figure 3. Relation between change in Isc following indomethacin $\left(10^{-6} \mathrm{M}\right.$, mucosal solution) and the initial Isc. Isc refers to the change in Isc measured 90 min after addition of indomethacin.
To determine if $\mathrm{Na}^{+}$absorption can also be chronically regulated we examined the effect of aldosterone. We chose to examine the effect of aldosterone because it is known to chronically regulate electrogenic $\mathrm{Na}^{+}$absorption in a variety of renal and intestinal epithelia (20). For these studies we used cultured epithelial cells because of the ease of manipulating the hormonal environment, i.e., the cells were grown in serum-free media with or without aldosterone $\left(10^{-6} \mathrm{M}\right)$. Table VI shows that monolayers exposed to aldosterone had a $50 \%$ higher Isc than those that did not receive aldosterone. Moreover, the inhibition of Isc by amiloride was $55 \%$ greater in the aldosterone-treated monolayers. After addition of amiloride, we added forskolin to stimulate $\mathrm{Cl}^{-}$secretion. The equivalent increase in Isc in both groups suggests that the $\mathrm{Cl}$ transport properties remained intact and were not altered by aldosterone.

\section{Discussion}

This study examined the acute and chronic regulation of $\mathrm{Na}^{+}$ absorption in canine tracheal epithelium. We found that several

Table II. Effect of Isoproterenol in the Presence of Indomethacin

\begin{tabular}{lll}
\hline & Isc & Isc \\
\hline & $\mu \mathrm{A} \mathrm{cm^{-2 }}$ & $\mu \mathrm{A} \mathrm{\textrm {cm } ^ { - 2 }}$ \\
Period 1 & Baseline & Baseline \\
& $15.6 \pm 6.5$ & $19.7 \pm 2.46$ \\
Period 2 & Control & Indomethacin \\
& $15.5 \pm 7.1$ & $10.1 \pm 1.9^{*}$ \\
Period 3 & Isoproterenol & Indomethacin and isoproterenol \\
& $19.4 \pm 7.1^{*}$ & $17.3 \pm 2.2^{*}$
\end{tabular}

Tissue pairs were studied in three consecutive periods: period 1, a baseline period; period 2, in which one of the tissue pairs received indomethacin $\left(10^{-6} \mathrm{M}\right.$, mucosal solution); and period 3, in which isoproterenol $\left(5 \times 10^{-6} \mathrm{M}\right)$ was added to the submucosal solution $(n=9$ pairs of tissues). * Indicates a statistical difference compared to the preceding period, $P<0.05$. 


\begin{tabular}{|c|c|c|c|c|c|c|}
\hline & \multicolumn{2}{|l|}{ Baseline } & \multicolumn{2}{|l|}{ Test } & \multicolumn{2}{|l|}{$\Delta$} \\
\hline & Isc & $G_{\mathrm{t}}$ & Isc & $G_{\mathrm{t}}$ & Isc & $G_{\mathrm{t}}$ \\
\hline & $\mu A \mathrm{~cm}^{-2}$ & $\mathrm{mS} \mathrm{cm^{-2 }}$ & $\mu \mathrm{A} \mathrm{cm}^{-2}$ & $m S \mathrm{~cm}^{-2}$ & $\mu A \mathrm{~cm}^{-2}$ & $\mathrm{mS} \mathrm{cm^{-2 }}$ \\
\hline Control & $31.7 \pm 7.8$ & $3.99 \pm 0.59$ & $27.4 \pm 8.0$ & $4.10 \pm 0.61$ & $-4.3 \pm 2.5$ & $+0.11 \pm 0.21$ \\
\hline 8-Br-cAMP & $29.9 \pm 9.5$ & $3.00 \pm 0.60$ & $38.2 \pm 13.7$ & $3.11 \pm 0.58$ & $+8.3 \pm 5.2^{*}$ & $+0.11 \pm 0.16$ \\
\hline
\end{tabular}

8-Br-cAMP $\left(5 \times 10^{-5} \mathrm{M}\right)$ was added to both the submucosal and mucosal bathing solutions. $(n=9$ pairs of tissues). * Indicates a statistical difference between the control and experimental tissues, $P<0.05$.

Table IV. Effect of A-23187 on Transepithelial Electrical Properties

\begin{tabular}{|c|c|c|c|c|c|c|}
\hline & \multicolumn{2}{|l|}{ Baseline } & \multicolumn{2}{|l|}{ Test } & \multicolumn{2}{|l|}{$\Delta$} \\
\hline & Isc & $G_{\mathrm{t}}$ & Isc & $G_{\mathrm{t}}$ & Isc & $G_{\mathrm{t}}$ \\
\hline & $\mu A \mathrm{~cm}^{-2}$ & $m S \mathrm{~cm}^{-2}$ & $\mu A \mathrm{~cm}^{-2}$ & $m S \mathrm{~cm}^{-2}$ & $\mu A \mathrm{~cm}^{-2}$ & $m S \mathrm{~cm}^{-2}$ \\
\hline Control & $41.9 \pm 18.8$ & $2.97 \pm 1.70$ & $43.3 \pm 17.5$ & $2.89 \pm 1.63$ & $+1.4 \pm 1.6$ & $-0.08 \pm 0.09$ \\
\hline A-23187 $\left(10^{-6} \mathrm{~m}\right)$ & $47.8 \pm 17.4$ & $4.82 \pm 0.81$ & $41.1 \pm 15.3$ & $4.75 \pm 0.88$ & $-6.7 \pm 3.1^{*}$ & $-0.07 \pm 0.17$ \\
\hline
\end{tabular}

All tissues were pretreated with 8-Br-cAMP $\left(5 \times 10^{-5}\right)$. Tissue pairs were studied in two consecutive periods: a baseline and a test period, during which $\mathrm{Ca}^{2+}$ ionophore A-23187 $\left(10^{-6} \mathrm{M}\right)$ was added to the mucosal solution. Values represent means $\pm \mathrm{SEM}$ for five pairs of tissues. ${ }^{*}$ Indicates a statistical difference between control and experimental tissues, $P<0.05$.

neurohumoral mediators, including isoproterenol, $\mathrm{PGE}_{2}$, and 2-chloroadenosine, acutely stimulate $\mathrm{Na}^{+}$absorption. The previous observation that these agents increase cellular levels of cAMP $(12,14)$, together with the finding that exogenous addition of cAMP also stimulates $\mathrm{Na}^{+}$absorption, suggests that cAMP may be the intracellular mediator responsible for regulating $\mathrm{Na}^{+}$ absorption. The data also suggest that endogenous prostaglandin production by the epithelium may regulate the baseline rate of $\mathrm{Na}^{+}$absorption under these conditions. The prostaglandin-synthesis inhibitor indomethacin decreased the spontaneous rate of $\mathrm{Na}^{+}$absorption without blocking the increase in $\mathrm{Na}^{+}$absorption produced by isoproterenol. Previous studies have shown that indomethacin decreases the rate of $\mathrm{PGE}_{2}$ production by the epithelium and decreases intracellular levels of cAMP in canine tracheal epithelium $(2,12)$.

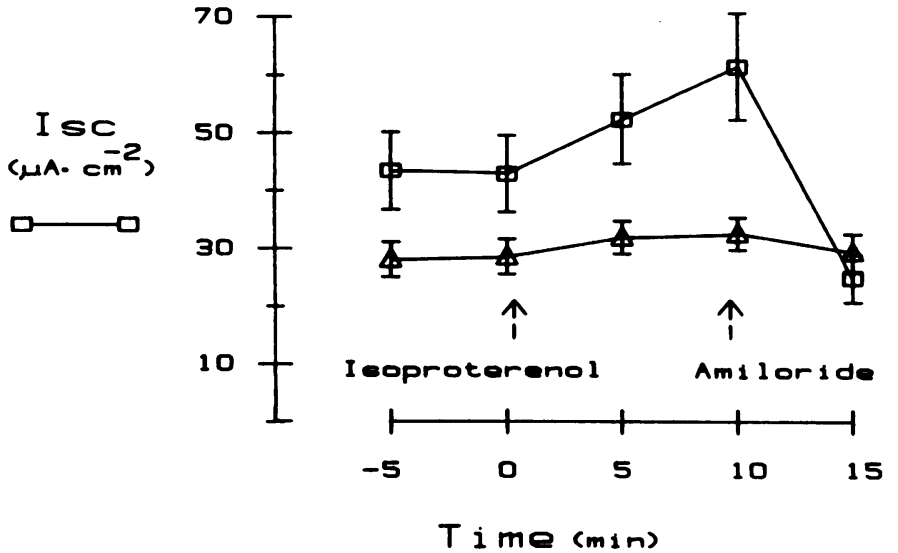

The parallels between the acute regulation of $\mathrm{Na}^{+}$absorption in this study and the acute regulation of $\mathrm{Cl}^{-}$secretion are interesting. Isoproterenol, $\mathrm{PGE}_{2}$, and 2-chloroadenosine stimulated $\mathrm{Na}^{+}$absorption in $\mathrm{Cl}^{-}$-free solutions; the same agents stimulate $\mathrm{Cl}^{-}$secretion in $\mathrm{Cl}^{-}$-containing solutions $(2,13,14)$. Exogenous cAMP stimulated $\mathrm{Na}^{+}$absorption in this study; it stimulates $\mathrm{Cl}^{-}$ secretion in the presence of $\mathrm{Cl}^{-}$(3). Prostaglandin production by the epithelium probably regulates the baseline rate of $\mathrm{Na}^{+}$ absorption in the absence of $\mathrm{Cl}^{-}$; prostaglandins also control the spontaneous rate of $\mathrm{Cl}^{-}$secretion in $\mathrm{Cl}^{-}$-containing media (2, $5,12)$. In contrast to these parallels, in $\mathrm{Cl}^{-}$-containing solutions, agents that stimulate $\mathrm{Cl}^{-}$secretion usually decrease or do not alter the rate of $\mathrm{Na}^{+}$absorption. The inhibition of $\mathrm{Na}^{+}$absorption associated with stimulation of $\mathrm{Cl}^{-}$secretion may be indirect, however, resulting from a decrease in the electrochemical gra-

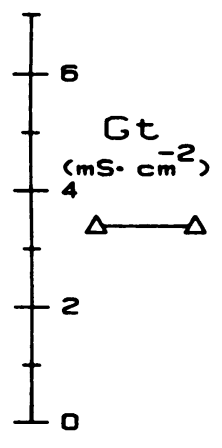

Figure 4. Effect of isoproterenol $\left(5 \times 10^{-6} \mathrm{M}\right.$, submucosal solution) and amiloride $\left(10^{-4} \mathrm{M}\right.$, mucosal solution) on Isc and $G_{t}$. Drugs were added at the times indicated $(n=6)$. 


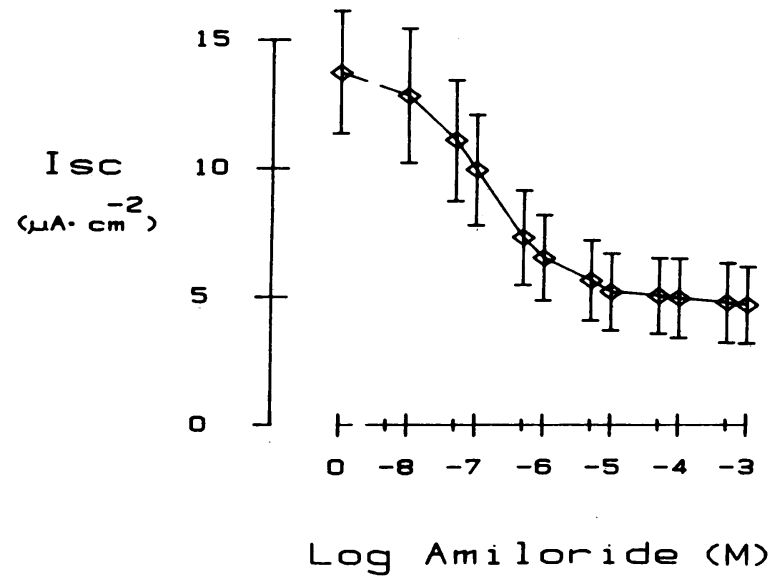

Figure 5. Effect of increasing concentrations of mucosal amiloride on the Isc of tissues treated with 8 -Br-cAMP $\left(5 \times 10^{-5} \mathrm{M}\right.$, mucosal solution) $(n=3)$.

dients for $\mathrm{Na}^{+}$absorption $(5,6)$, thereby masking any direct effect of hormones on the $\mathrm{Na}^{+}$transport pathway. The advantage of this study is that the use of $\mathrm{Cl}^{-}$-free solutions allowed us to directly examine the effect of these agents on $\mathrm{Na}^{+}$absorption without secondary effects produced by changes in electrochemical gradients.

The observation that cAMP acutely stimulates $\mathrm{Na}^{+}$absorption in airway epithelia is similar to findings in another lung epithelium, cultured monolayers of alveolar type II cells. Exogenous addition of cAMP or $\beta$-adrenergic agonists increased the rate of dome formation in type II cells grown on impermeable supports (21) and increased the Isc of cells grown on permeable supports (22). These results suggest stimulation of $\mathrm{Na}^{+}$absorption by alveolar epithelium. Cyclic-AMP mediated stimulation of $\mathrm{Na}^{+}$absorption has also been observed in amphibian urinary bladder and amphibian skin (23-25). In these epithelia, antidiuretic hormone stimulation of electrogenic $\mathrm{Na}^{+}$absorption is mediated by an increase in cellular levels of cAMP.

The data also suggest that an increase in intracellular $\mathrm{Ca}^{2+}$ may inhibit $\mathrm{Na}^{+}$absorption. When the rate of $\mathrm{Na}^{+}$absorption was increased by isoproterenol, the calcium ionophore A-23187 decreased the Isc. An inhibition of $\mathrm{Na}^{+}$absorption by an increase in the intracellular $\mathrm{Ca}^{2+}$ concentration has also been observed in renal epithelia and is thought to result from inhibition of apical $\mathrm{Na}^{+}$channels (15-17).

One other study that suggests acute regulation of $\mathrm{Na} \mathrm{ab}-$ sorption in the airway epithelium is that of Legris et al. (26). In baboon bronchus mucosal addition of harmaline, which is present in airway APUD (amine-precursor-uptake-and-decarboxylation) cells, inhibited $\mathrm{Na}^{+}$absorption. The inhibition by harmaline may result from a direct, amiloride-like block of apical $\mathrm{Na}^{+}$channels.

In addition to acute regulation, the data indicate that $\mathrm{Na}^{+}$ absorption is chronically regulated by aldosterone. This result is consistent with the observations of Hopfer and Legris (personal communication). They observed that volume depletion in patients with cystic fibrosis was associated with an increase in serum aldosterone concentration and an increase in the transepithelial voltage of the upper airway.

Our study has some limitations. First, the conditions for studying acute regulation are artificial, in that the bathing solutions contain no $\mathrm{Cl}^{-}$. On the one hand, $\mathrm{Cl}^{-}$-free media might alter intracellular metabolism or unknown intracellular regulatory steps. On the other hand, the study would not have been possible without the use of $\mathrm{Cl}^{-}$-free solutions. We considered the alternative of using agents that block $\mathrm{Cl}^{-}$secretion. Unfortunately, however, neither loop diuretics which block $\mathrm{Cl}^{-}$entry into the cell $(7,18)$ nor carboxylic acid analogues that block the $\mathrm{Cl}$ channel (27), completely abolish $\mathrm{Cl}$ secretion. Moreover the use of loop diuretics to inhibit $\mathrm{Cl}$ secretion would not have prevented the cAMP-induced increase in apical $\mathrm{Cl}^{-}$conductance with possible effects on apical membrane voltage. Finally, these drugs might have other unrecognized effects; certainly carboxylic acid analogues have injurious effects with prolonged incubation (27). Second, this study does not allow us to address the mechanism by which $\mathrm{Na}^{+}$absorption is increased. Although an increase in the apical $\mathrm{Na}^{+}$permeability is a reasonable explanation, stimulation of the Na-K-ATPase or an increase in basolateral $\mathrm{K}^{+}$permeability (which would increase the electrical driving force for $\mathrm{Na}^{+}$entry) might also account for stimulation of $\mathrm{Na}^{+} \mathrm{ab}-$ sorption.

One unexplained observation in this study is that Isc did not decrease to zero following addition of amiloride. If all of the current were due to electrogenic $\mathrm{Na}^{+}$absorption we would have expected amiloride to completely inhibit it. However, it seems unlikely that other transport processes would be accounting for the current: $\mathrm{HCO}_{3}^{-}$secretion is unlikely as the solutions are $\mathrm{HCO}_{3}^{-}$and $\mathrm{CO}_{2}$ free; $\mathrm{H}^{+}$secretion would produce a negative value of Isc; significant $\mathrm{K}$ absorption seems unlikely based on previous studies $(28,29)$ and the low concentration of $K$ in the solutions; and finally, most other electrically neutral transport processes that might indirectly be involved either require $\mathrm{Cl}^{-}$or $\mathrm{HCO}_{3}^{-}$or are inhibited by high $(1 \mathrm{mM})$ concentrations of amiloride (i.e., $\mathrm{Na}^{+}-\mathrm{H}^{+}$exchange, see Fig. 5). It is possible that,

Table V. Effect of Isoproterenol on Electrical Properties and $\mathrm{Na}^{+}$Fluxes

\begin{tabular}{llllll}
\hline & Isc & $G_{\mathrm{t}}$ & $\mathrm{J}$ & $\mathrm{J}$ & $\mathrm{J}$ \\
\hline & $\mu e q \cdot \mathrm{cm}_{\mathbf{m}}^{-2} h^{-1}$ & $m S \cdot \mathrm{cm}_{\mathrm{m}}^{-2}$ & $\mu e q \cdot \mathrm{cm}^{-2} h^{-1}$ & $\mu e q \cdot \mathrm{cm}^{-2} h^{-1}$ & $\mu e q \cdot \mathrm{cm}^{-2} h^{-1}$ \\
Control & $0.34 \pm 0.12$ & $2.67 \pm 0.39$ & $2.45 \pm 0.68$ & $2.31 \pm 0.46$ & $0.14 \pm 0.52$ \\
Isoproterenol & $0.68 \pm 0.20$ & $2.89 \pm 0.45$ & $3.22 \pm 0.77$ & $2.70 \pm 0.50$ & $0.53 \pm 0.51$ \\
$\Delta$ & $0.31 \pm 0.09^{*}$ & $0.22 \pm 0.06^{*}$ & $0.77 \pm 0.24^{*}$ & $0.39 \pm 0.23^{*}$ & $0.39 \pm 0.16^{*}$ \\
\hline
\end{tabular}

Indomethacin $\left(10^{-6} \mathrm{M}\right)$ was present in the mucosal solution during both periods. $\mathrm{J}_{\mathrm{ms}}^{\mathrm{Na}}, \mathrm{J}_{\mathrm{sm}}^{\mathrm{Na}}$, and $\mathrm{J}_{\mathrm{Net}}^{\mathrm{Na}}$ refer to $\mathrm{Na}^{+}$flux from mucosal to submucosa, submucosa to mucosa, and the calculated net flux, respectively ( $n=9$ tissue pairs). ${ }^{*}$ Value different from zero, $P<0.05$. 
Table VI. Effect of Aldosterone on Isc

\begin{tabular}{llllll}
\hline & Baseline & Amiloride & $\Delta$ Amiloride & Forskolin & \multicolumn{1}{c}{$\Delta$ Forșkolin } \\
\hline Control & $2.6 \pm 0.3$ & $0.7 \pm 0.3$ & $-1.8 \pm 0.2$ & $9.3 \pm 0.8$ & $+8.6 \pm 0.8$ \\
Aldosterone & $3.9 \pm 0.5^{*}$ & $1.1 \pm 0.4$ & $-2.8 \pm 0.3^{*}$ & $9.1 \pm 1.0$ & $+8.0 \pm 0.8$
\end{tabular}

Values of Isc (in microamperes per square centimeter) were measured in cultured monolayers under baseline conditions, following addition of amiloride $\left(10^{-4}\right)$ to the mucosal solution and then after forskolin $\left(10^{-5}\right)$ was added to the mucosal solution. $\Delta$ Amiloride and $\Delta$ forskolin refer to the change in Isc following addition of these agents. Values are from 11 control monolayers and 9 monolayers in which the media contained aldosterone $(1 \mu \mathrm{M}){ }^{*}$ Value different from control, $P<0.02$.

under these conditions, amiloride does not inhibit all of the electrogenic $\mathrm{Na}^{+}$absorption. In support of this suggestion are the observations that in canine and bovine tracheal epithelium bathed in $\mathrm{Cl}^{-}$containing solution amiloride did not completely inhibit electrogenic $\mathrm{Na}^{+}$absorption $(4,30)$.

These observations may be important in understanding abnormalities of airway epithelial ion transport in cystic fibrosis (CF). The airway epithelia from patients with $\mathrm{CF}$ are $\mathrm{Cl}^{-}$impermeable $(31,32)$, a defect that has been localized to the apical cell membrane (33). An increase in the rate of $\mathrm{Na}^{+}$absorption has also been observed (34). In addition, Boucher et al. (34) found that in CF nasal epithelia isoproterenol stimulated amiloride-sensitive $\mathrm{Na}^{+}$absorption, rather than stimulating $\mathrm{Cl}^{-}$secretion as it does in normal airways. We speculate that the stimulation of $\mathrm{Na}^{+}$absorption in a $\mathrm{Cl}^{-}$impermeable $\mathrm{CF}$ epithelium may have some similarities to stimulation of $\mathrm{Na}^{+}$absorption in a normal tracheal epithelium in which $\mathrm{Cl}^{-}$has been removed. cAMP-mediated stimulation of $\mathrm{Na}^{+}$absorption thus might be a normal process in airway epithelia that is uncovered by the $\mathrm{Cl}^{-}$impermeability in $\mathrm{CF}$.

\section{Acknowledgments}

We thank Phil Karp, John A. Girotto, and Vanessa Krumbholz for excellent technical assistance and Drs. Victor Schuster, Russ Husted, and Larry Karnisky for reading the manuscript.

Supported by grants from the National Institutes of Health (HL29851) and the Council for Tobacco Research. This work was performed while J. J. Cullen was a Senior Honors Student. M. J. Welsh is an Established Investigator of the American Heart Association.

\section{References}

1. Olver, R. E., B. Davis, M. G. Marin, and J. A. Nadel. 1975. Active transport of $\mathrm{Na}^{+}$and $\mathrm{Cl}^{-}$across the canine tracheal epithelium in vitro. Am. Rev. Respir. Dis. 112:811-815.

2. Al-Bazzaz, F., V. P. Yadava, and C. Westenfelder. 1981. Modification of $\mathrm{Na}$ and $\mathrm{Cl}$ transport in canine tracheal mucosa by prostaglandins. Am. J. Physiol. 240:F101-F105.

3. Al-Bazzaz, F. J. 1981. Role of cyclic AMP in regulation of chloride secretion by canine tracheal mucosa. Am. Rev. Respir. Dis. 123:295298.

4. Widdicombe, J. H., and M. J. Welsh. 1980. Ion transport by dog tracheal epithelium. Fed. Proc. 39:3062-3066.

5. Welsh, M. J., P. L. Smith, and R. A. Frizzell. 1982. Chloride secretion by canine tracheal epithelium. II. The cellular electrical potential profile. J. Membr. Biol. 70:227-238.

6. Shorofsky, S. R., M. Field, and H. A. Fozzard. 1986. Changes in intracellular sodium with chloride secretion in dog tracheal epithelium. Am. J. Physiol. 250:C646-C650.

7. Welsh, M. J. 1983. Inhibition of chloride secretion by furosemide in canine tracheal epithelium. J. Membr. Biol. 71:219-226.

8. Christoffersen, F. G. J., and L. H. Skibstedt. [1975]. Calcium ion activity in physiological salt solutions. Influence of anions substituted for chloride. Comp. Biochem. Physiol. 52A:317-322.

9. Marin, M. G., and M. M. Zaremba, 1978. Effect of calcium on ion transport and electrical properties of tracheal epithelium. J. Appl. Physiol. (Respir. Environ. Exercise Physiol.) 44:900-904.

10. Coleman, D, L., I. K. Tuet, and J. H. Widdicombe. 1984. Electrical properties of dog tracheal epithelial cells grown in monolayer culture. Am. J. Physiol. 246:C355-C359.

11. Welsh, M. J. 1985. Ion transport by primary cultures of canine tracheal epithelium. Methodology, morphology and electrophysiology. J. Membr. Biol. 88:149-163.

12. Smith, P. L., M. J. Welsh, J. S. Stoff, and R. A. Frizzell. 1982. Chloride secretion by canine tracheal epithelium. Role of intracellular cAMP levels. J. Membr. Biol. 70:217-226.

13. Al-Bazzaz, F. J., and E. Cheng. 1979. Effect of catecholamines on ion transport in dog tracheal epithelium. J. Appl. Physiol. 47:397403.

14. Pratt, A. D., G. Clancy, and M. J. Welsh. 1986. Mucosal adenosine stimulates chloride secretion in canine tracheal epithelium. Am. J. Physiol. 251:C167-C174.

15. Taylor, A., and E. E. Windhager. 1979. Possible role of cytosolic calcium and $\mathrm{Na}-\mathrm{Ca}$ exchange in regulation of transepithelial sodium transport. Am. J. Physiol. 236:F505-F512.

16. Windhager, E. E., and A. Taylor. 1983. Regulatory role of intracellular calcium ions in epithelial Na transport. Annu. Rev. Physiol. 45: 519-532.

17. Chase, H. S. 1984. Does calcium couple the apical and basolateral membrane permeabilities in epithelia? Am. J. Physiol. 247:F869-F876.

18. Widdicombe, J. H., I. T. Nathanson, and E. Highland, 1983. Effects of "loop" diuretics on ion transport by dog tracheal epithelium. Am. J. Physiol. 245:C388-C396.

19. Cuthbert, A. W., J. M. Edwardson, J. Aceves, and S. A. Wilson. 1979. Amiloride as a membrane probe. In Amiloride and Epithelial Sodium Transport. A. W. Cuthbert, G. M. Fanelli, Jr., and A. Scriabine, editors. Urban and Schwarzenbert, Inc., Baltimore-Munich. 113-123.

20. Scott, W. N., and D. B. P. Goodman, editors. 1981. Hormonal regulation of epithelial transport of ions and water. Ann. NY Acad. Sci. Vol. 372.

21. Crandall, E. D., S. E. S. Brown, and B. E. Goodman. 1983. Regulation of transport across alveolat epithelial cell monolayers by cAMP. Am. Rev. Respir. Dis. 127:306.

22. Cott, G. R., K. S. Sugahara, and R. J. Mason. 1983. Cyclic adenosine monophosphate is a modulator of the bioelectric properties of alveolar type II cell monolayers. Physiologist. 26:A125.

23. Orloff, J., and J. S. Handler. 1962. The similarity of effects of vasopressin and adenosine $3^{\prime}, 5^{\prime}$-phosphate (cyclic AMP) and theophylline on the toad bladder. J. Clin. Invest. 41:702-709.

24. Baba, W. I., A. J. Smith, and M. M. Towsend. 1967. The effect of vasopressin, theophylline, and cyclic 3',5'-adenosine monophosphate (cyclic AMP) on sodium transport across the frog skin. Q. J. Exp. Physiol. $52: 410-421$.

25. Els, W. J., and S. I. Helman. 1981. Vasopressin, theophylline, $\mathrm{PGE}_{2}$, and indomethacin on active $\mathrm{Na}$ transport in frog skin. Studies with microelectrodes. Am. J. Physiol. 241;F279-F288.

26. Legris, G. J., P. C. Will, and V. Hopfer. Inhibition of amiloridesensitive sodium conductance by indoleamines. 1982. Proc. Natl. Acad. Sci. USA. 79:2046-2050. 
27. Welsh, M. J. 1984. Anthracene-9-carboxylic acid inhibits an apical membrane chloride conductance in canine tracheal epithelium. J. Membr. Biol. 78:61-71.

28. Welsh, M. J. 1983. Evidence for a basolateral membrane potassium conductance in canine tracheal epithelium. Am. J. Physiol. 244: C377-C384.

29. Smith, P. L., and R. A. Frizzell. 1984. Chloride secretion by canine tracheal epithelium: basolateral membrane $\mathrm{K}$ permeability parallels secretion rate. J. Membr. Biol. 77:187-199.

30. Langridge-Smith, J. E. 1986. Interaction between sodium and chloride transport in bovine tracheal epithelium. J. Physiol. 376:299319.

31. Knowles, M. R., M. J. Stutts, A. Spock, N. Fischer, J. T. Gatzy, and R. C. Boucher. 1983. Abnormal ion permeation through cystic fibrosis respiratory epithelium. Science (Wash. DC). 221:1067-1070.

32. Knowles, M., J. Gatzy, and R. Boucher. 1983. Relative ion permeability of normal and cystic fibrosis nasal epithelium. J. Clin. Invest. 71:1410-1417.

33. Widdicombe, J. H., M. J. Welsh, and W. E. Finkbeiner. 1985. Cystic fibrosis decreases the apical membrane chloride permeability of monolayers cultured from cells of tracheal epithelium. Proc. Natl. Acad. Sci. USA. 82:6167-6171.

34. Boucher, R. C., M. J. Stutts, M. R. Knowles, L. Cantlye, and J. T. Gatzy. 1985. Net transport in cystic fibrosis nasal epithelia: Abnormal basal rate and response to adenylate cyclase activation. Clin. Res. 33: 467a. (Abstr.) 